\title{
Implementation of the HACCP tool and microbiological quality of agbelima production on a site in South Benin
}

\author{
D. Sc. Micheline AGASSOUNON DJIKPO TCHIBOZO ${ }^{1}$, Romaine CAPO-CHICHI, \\ $D$. Antoinette ADJAGODO ${ }^{1}, D$. Eléonore LADEKAN ${ }^{1}, D$. Sc. Tognon Clotilde GUIDI ${ }^{2}$, \\ $D$. Sc. Larissa V. GALIMOVA ${ }^{3}$ \\ ${ }^{1}$ University of Abomey (UAC), Benin, BP. Cotonou $526 / 01$ \\ ${ }^{2}$ National Higher Institute of Technology of Lokossa/ National University of Sciences, Technologies, \\ Engineering and Mathematics of Benin, BP 133 Lokossa \\ ${ }^{3}$ Astrakhan State Technical University, Russia \\ E-mail: guidi65@mail.ru
}

The Hazard Analysis and Critical Control Point system (HACCP) is a scientific and systematic approach to identify hazards and provide measures for their control to ensure food safety. Thus, to ensure that the quality of agbélima, a product derived from cassava is taken into consideration during processing, the HACCPsstem has been applied to improve both the quality and the safety of that product. The methodology used for the implementation of the quality approach on the chain of production of agbelima in South Benin is summarized by a survey for the analysis of the context and the environment of agbelima production, the hazard analysis and the determination of the critical points related to the production of agbelima, the realization of the model of the quality assurance system (HACCP) and the verification of the effectiveness of the system implemented. The hazard analysis was carried out according to the raw, material, labor, equipment, environment and method. The elaboration of the HACCP theorical model was carried out according to twelve classic steps. The HACCP system is implemented on the production site. Before and after the implementation of the system, microbiological analysis on eighteen samples of agbelima were carried out. The results of the hazard analysis indicate that hazards exist at all stages of agbelima production. The application of the HACCP theorical model resulted in the detection of 6 Critical Control Points (CCPs) throughout the production chain. These are the reception of the raw material, washing, grinding, pressing, fine milling, and packaging. The analysis reveals that all eighteen samples of agbelima analysed before the implementation of the approach are not in conformity with the regulatory requirements. However, after the application of the system, a varying reduction from $93.49 \%$ to $100 \%$ was noted for microorganisms such as: Total Mesophilic Flora, Lactic Flora, Yeasts and Moulds and Sulfito Reducing Anaerobes, ColiformsThermotolerant, E. coli, Staphylococci and Salmonella in agbelima samples. Compliance with the implementation guide is $77.5 \%$ in relation to twelve steps of the system application. Improvements are needed on the records and their effective updating to maintain the level of quality of this product.

Keywords: cassava, agbelima, HACCP, quality, Benin.

\section{Article info:}

Received 11/05/2021, accepted 25/06/2021

DOI: $10.17586 / 1606-4313-2021-20-3-45-56$

Article in English

For citation:

Agassounon Djikpo Tchibozo M., Capo-Chichi R., Adjagodo A., Ladekan E., Guidi T. C., Galimova L. V.

Implementation of the HACCP tool and microbiological quality of agbelima production on a site in South Benin. Journal of International Academy of Refrigeration. 2021. No 3. p. 45-56. DOI: 10.17586/1606-4313-2021-20-3-45-56

\section{Внедрение системы анализа опасностей и критических контрольных точек и микробиологическое качество продукции агбелима на участке в Южном Бенине}

Д-р биол. наук М. АГАССУНОН ЖИКПО ЩИБОЗО ${ }^{1}$, Р. КАПО-ШИШИ ${ }^{1}$, канд. биотехн. наук А. АДЖАГОДО', канд. биотехн. наук Е. ЛАДЕКАН ${ }^{1}, \partial-p$ техн. наук Т. К. ГУИДИ ${ }^{2}$, д-р техн. наук Л. В. ГАЛИМОВА

${ }^{1}$ Университет Абомеу Калави, Бенин

${ }^{2}$ Локосский государственный технологический институт, Национальньй университет наук, технологий, инженерии и математики Бенина, ВР 133 Локосса

${ }^{3}$ Астраханский государственный технический университет, Россия

E-mail: guidi65@mail.ru

Система анализа опасностей и критических контрольных точек (НАССР) - это научный и систематический подход к выявлению опасностей и обеспечению мер по их контролю для того, чтобы гарантирвоать 
безопасность пищевых продуктов. Целью работы является применение системы НАССР для обеспечеия качества и безопасности агбелима - продукта, полученного из маниоки во время его обработки. Методология, использованная для реализации подхода к качеству в цепочке производства агбелима в Южном Бенине, представтлена обзором условий производства агбелима, анализом рисков и определением критических точек, связанных с его производством, реализацией модели системы обеспечения качества (НАССР) и проверкой эффективности внедренной системы. Анализ опасностей проводился в соответствии с сырьем, материалами, рабочей силой, оборудованием, окружающей средой и методом. Разработка теоретической модели НАССР проводилась по 12 классическим шагам. Система НАССР внедрена на производственной площадке. До и после внедрения системы был проведен микробиологический анализ 18 образцов агбелима. Результаты анализа показывают, что опасности существуют на всех этапах производства агбелима. Применение теоретической модели НАССР привело к обнаружению 6 критических контрольных точек (ККТ) по всей производственной цепочке. Это прием сырья, мойка, измельчение, прессование, тонкое измельчение и упаковка. Анализ показывает, что все 18 образцов агбелима, проанализированные до реализации подхода, не соответствуют нормативным требованиям. Однако после применения системы было отмечено от 93,49\% до $100 \%$ снижения содежания таких микроорганизмов, как общая мезофильная флора, молочная флора, дрожжи и плесень, а такэе сульфиторедуцирующие анаэробы, термотолерантные колиформные бактерии, кишечная палочка, стафилококки и сальмонелла в образцах агбелима. Соответствие руководству по внедрению системы - 77,5\% по 12 шагам ее применения. Необходимы улучшения проткола и его эффективное обновление для поддержания уровня качества этого продукта.

Ключевые слова: маниока, агбелима, НАССР, качество, Бенин.

\section{Информация о статье:}

Поступила в редакцию 11.05.2021, принята к печати 25.06.2021

DOI: $10.17586 / 1606-4313-2021-20-3-45-56$

Язык статьи - английский

Для цитирования:

Agassounon Djikpo Tchibozo M., Capo-Chichi R., Adjagodo A., Ladekan E., T.C. Guidi, Galimova L.V. Implementation of the HACCP tool and microbiological quality of agbelima production on a site in South Веnin // Вестник Международной академии холода. 2021. № 3. C. 45-56. DOI: 10.17586/1606-4313-2021-20-3-45-56

\section{Introduction}

Cassava (Manihot esculenta Crantz) is the most important tropical root crops. It constitutes the fourth largest crops production in terms of its contribution $(92,842,000$ tons in 1992) to the world population's diet after cereals (Bokanga, 2001 [22]). Its annual world production is estimated at about 237 million tons in 2010.

Its cultivation in Sub-Saharan Africa is the second after other staple food crops and it plays a major role in food security (Benesi et $a l ., 2005$ [20]). Indeed, on food plan, the consumption of roots constitutes an important source of calories for the populations of developing countries (Turyagyenda et al., 2012 [45]). Cassava roots are known as the best producer of carbohydrates (sugars) among commodity crops. In order to be consumed, this starchy root needs to undergo several food processing technologies (Amoa-Awua et al., 1996 [18]; Toka et al., 2008 [44]), which are highly dependent on different regions and countries.

In Benin, cassava tends to become a crop contributing to poverty reduction through the marketing of its many derivatives (gari, tapioca, lafun, cossette, agbelima, etc.) (Hongbètè et al., 2011 [29]; Abraham, 2013 [2]). One of the products derived from cassava is agbelima, which is made from cassava roots and is used to prepare a paste commonly called agbéli; the latter is consumed by $66.66 \%$ of Beninese in South Benin (Capo-chichi, 2010 [24]). Today, this food occupies an important place in the eating habits at home and in the restaurants of Beninese society.
Despite this strong involvement of this product, the quality of agbelima still leaves something to be desired because of the shortcomings that can be seen along the processing circuit. It has been reported that several traditional technologies have shortcomings that can influence the quality of finished products (Konfo et al., 2014 [30]). Failure to comply with hygienic and packaging conditions means that the finished product may be responsible for certain diseases such as toxi-infections among consumers (Agassounon Djikpo Tchibozo et al., 2016 [12]).

In order to guarantee the quality of this foodstuff that has become almost unavoidable in food habits, the HACCP system has been developed to manage the quality and hygiene of food along the processing chain. This system detects risk factors that may exist and makes it possible to control risk areas by putting in place safeguards (Mananga Luzembo, 2012 [33]).

The aim of this work is to assess the effectiveness of the application of the rules of Good Hygiene Practices/Manufacturing according to the HACCP system, as part of the improvement of the quality of agbelima produced in South Benin.

\section{Material and Methods}

\subsection{Study Framework}

The study focused on an agbelima production site in southern Benin. Southern Benin is characterized by a humid tropical or sub-equatorial (Beninese) climate with four seasons of unequal duration: two rainy seasons alternating with two dry seasons. The average annual temperature varies 
from $25^{\circ} \mathrm{C}$ to $29^{\circ} \mathrm{C}$ (Le Barbé, 1993 [31]). Atmospheric humidity is high in this region and is of the order of $85 \%$ in January and February; it reaches a maximum of $95 \%$ in October.

\subsection{Plant material}

The study material is agbelima, a derivative of Manihot esculenta Crantz, a species of the Euphorbiaceae family that produces high energy roots used in human food (Akouègninou et al., 2006 [17]).

\subsection{Methodologies}

The work includes three steps: a survey was conducted among the producer (s) to record the general hygiene of the place of production, identify the different diagrams of agbelima production and then the context and environment of agbelima production. Then the evaluation of the knowledge of hazards, the identification of hazards during operations and the establishment of corrective actions followed by microbiological analysis were carried out. All this was done to verify the efficiency of the system put in place by considering lactic flora and contamination (Bourgeois and Leveau, 1991 [23]).

\subsubsection{Investigation}

The purpose of the survey is to obtain useful information on the state of hygiene at the agbelima production site. It was carried out using an on-site observation sheet (Agassounon Djikpo Tchibozo et al., 2014 [11]) and follow-up after agreement with the producers. The observation grid used enabled the observation of breaches of hygiene rules during production.

\subsubsection{Realization and application of the HACCP model}

The realization of the theoretical model followed the 12 regulatory steps of HACCP implementation. After the HACCP team was set up and the product was described, its intended use was determined (Steps 1, 2 and 3).

A preliminary audit was carried out on the production site. A meeting with the person in charge and his workforce was done according to the approach already reported by Agassounon Djikpo Tchibozo et al (2016) [12]. Its objective was to record the details relating to the context and the environment of agbelima production on these sites and to verify on site the theorical diagram retained; as well as the flow chart in order to complete them and correct them if necessary. That in full compliance with steps 4 and 5 of the HACCP system implementation. For the safety of consumers, potential hazards that could hinder the marketable, hygienic and nutritional quality of the product have been identified during the production process throughout the chain. The HACCP team, being a monitoring team, was set up for field investigations. Critical Control Points (CCPs) were identified with critical limits. The monitoring system was developed as well as the corrective actions. Suggestions were done. Then a documentation system was produced.

\subsubsection{Verification of the effectiveness of the system put} in place

The system set up has been verified by microbiological analysis carried out before and after the application of the HACCP principle.

\subsubsection{Sampling}

The control carried out concerns the actual production of agbelima and covered 3 (three) technologies and two cultivars (Agrick and Hombete) of cassava. A total of 18 agbelima samples of the two cultivars were taken and analyzed, 3 samples from each technology. Sampling was done aseptically after production following the procedure described in the standard method NF V 04-501: 1998 [8] before and after the application of the HACCP system. Each sample of a minimum mass of $100 \mathrm{~g}$ was taken and packaged in a sterile sampling bag fitted with sealing bars, then protected in plastic containers and identified by a label with a direct marking of their code on the plastic packaging. The samples were transported as soon as possible in a cooler equipped with a freshness accumulator to the laboratory where they were processed immediately. These samples were distributed according to the sample codes described in Table 1.

\begin{tabular}{|c|c|c|}
\hline \multicolumn{3}{|c|}{ Sample codes } \\
\hline \multicolumn{2}{|c|}{ Codes } & Samples \\
\hline \multirow{3}{*}{$\mathrm{AT}_{1} \mathrm{~A}_{\mathrm{g}}$} & $\mathrm{A}_{1} \mathrm{~T}_{1} \mathrm{~A}_{\mathrm{g}}$ & \multirow{3}{*}{$\begin{array}{c}\text { Agbelima from Technology } 1 \text { with } \\
\text { agrick cultivar }\end{array}$} \\
\hline & $\mathrm{A}_{2} \mathrm{~T}_{1} \mathrm{~A}_{\mathrm{g}}$ & \\
\hline & $\mathrm{A}_{3} \mathrm{~T}_{1} \mathrm{~A}_{\mathrm{g}}$ & \\
\hline \multirow{3}{*}{$\mathrm{AT}_{2} \mathrm{~A}_{\mathrm{g}}$} & $\mathrm{A}_{1} \mathrm{~T}_{2} \mathrm{~A}_{\mathrm{g}}$ & \multirow{3}{*}{$\begin{array}{c}\text { Agbelima from Technology } 2 \text { with } \\
\text { agrick cultivar }\end{array}$} \\
\hline & $\mathrm{A}_{2} \mathrm{~T}_{2} \mathrm{~A}_{\mathrm{g}}$ & \\
\hline & $\mathrm{A}_{3} \mathrm{~T}_{2} \mathrm{~A}_{\mathrm{g}}$ & \\
\hline \multirow{3}{*}{$\mathrm{AT}_{3} \mathrm{~A}_{\mathrm{g}}$} & $\mathrm{A}_{1} \mathrm{~T}_{3} \mathrm{~A}_{\mathrm{g}}$ & \multirow{3}{*}{$\begin{array}{c}\text { Agbelima from Technology } 3 \text { with } \\
\text { agrick cultivar }\end{array}$} \\
\hline & $\mathrm{A}_{2} \mathrm{~T}_{3} \mathrm{~A}_{\mathrm{g}}$ & \\
\hline & $\mathrm{A}_{3} \mathrm{~T}_{3} \mathrm{~A}_{\mathrm{g}}$ & \\
\hline \multirow{3}{*}{$\mathrm{AT}_{1} \mathrm{H}$} & $\mathrm{A}_{1} \mathrm{~T}_{1} \mathrm{~A}_{\mathrm{H}}$ & \multirow{3}{*}{$\begin{array}{c}\text { Agbelima from Technology } 1 \text { with } \\
\text { Hombètè cultivar }\end{array}$} \\
\hline & $\mathrm{A}_{2} \mathrm{~T}_{1} \mathrm{~A}_{\mathrm{H}}$ & \\
\hline & $\mathrm{A}_{3} \mathrm{~T}_{1} \mathrm{~A}_{\mathrm{H}}$ & \\
\hline \multirow{3}{*}{$\mathrm{AT}_{2} \mathrm{H}$} & $\mathrm{A}_{1} \mathrm{~T}_{2} \mathrm{~A}_{\mathrm{H}}$ & \multirow{3}{*}{$\begin{array}{c}\text { Agbelima from Technology } 2 \text { with } \\
\text { Hombètè cultivar }\end{array}$} \\
\hline & $\mathrm{A}_{2} \mathrm{~T}_{2} \mathrm{~A}_{\mathrm{H}}$ & \\
\hline & $\mathrm{A}_{3} \mathrm{~T}_{2} \mathrm{~A}_{\mathrm{H}}$ & \\
\hline \multirow{3}{*}{$\mathrm{AT}_{3} \mathrm{H}$} & $\mathrm{A}_{1} \mathrm{~T}_{3} \mathrm{~A}_{\mathrm{H}}$ & \multirow{3}{*}{$\begin{array}{c}\text { Agbelima from Technology } 3 \text { with } \\
\text { Hombètè cultivar }\end{array}$} \\
\hline & $\mathrm{A}_{2} \mathrm{~T}_{3} \mathrm{~A}_{\mathrm{H}}$ & \\
\hline & $\mathrm{A}_{3} \mathrm{~T}_{3} \mathrm{~A}_{\mathrm{H}}$ & \\
\hline
\end{tabular}

2.3.3.2. Study of the microbiological quality of agbelima samples

Microbiological analysis including market and hygienic quality (Bourgeois and Leveau, 1991 [23]) before and after HACCP were performed on agbelima samples in accordance with the NF ISO 7218 [6] standard, laying down general rules for microbiological examinations. The market quality took into account visual and sensory aspects. The different parameters researched are: Total Mesophilic Flora, Lactic Flora, Coliforms thermotolerant, Escherichia coli, Staphylococcus aureus, Yeasts and Molds, Sulfito Reducing Anaerobes and Salmonella (Table 2).

Before moving on to sowing inoculation, the stock suspensions were prepared in accordance with the standard (NF V 08-051:1999 [9]). Successive dilutions, based on the standard (NB $0111007-2006$ [13]), were obtained by placing $1 \mathrm{ml}$ of the previous dilution in $9 \mathrm{ml}$ of diluent as the tests progressed.

The results were expressed in Colony Forming Units (CFU)/g of product analyzed. The interpretation of the results is done with reference to the standards from the lafun guide value (criteria published by the National Agency for Stan- 
Methods of detection and enumeration of bacterial and fungal microflora

Table 2

\begin{tabular}{|c|c|c|c|c|}
\hline \multicolumn{2}{|c|}{ Search for germs and methods used } & Types of sowing & Cultivation media & Cultivation conditions \\
\hline \multicolumn{2}{|c|}{ FMT (NB 01.11.008-2006 [14]) } & $1 \mathrm{ml}$ in the mass & Gélose PCA & $48 \mathrm{H} \pm 2$ at $30^{\circ} \mathrm{C}$ \\
\hline \multicolumn{2}{|c|}{$\begin{array}{l}\text { Coliforms thermotolerant } \\
\text { (NF ISO 4832-2006 [4]) }\end{array}$} & $1 \mathrm{ml}$ in the mass & Violet Red Bile Lactose Agar & $24 \mathrm{H} \pm 2$ at $44^{\circ} \mathrm{C}$ \\
\hline \multicolumn{2}{|c|}{$\begin{array}{l}\text { Yeasts and Moulds } \\
\text { (NF ISO 7954-1998/V08-022 [7]) }\end{array}$} & $0.1 \mathrm{ml}$ on the surface & Potato Dextrose Agar & 5 days at $25^{\circ} \mathrm{C}$ \\
\hline \multicolumn{2}{|c|}{$\begin{array}{l}\text { Staphylococcusaureus } \\
\text { (NF ISO 6888-1-1999 [5]) }\end{array}$} & $0.1 \mathrm{ml}$ on the surface & Baird Parker complete & $48 \mathrm{H} \pm 2$ at $37^{\circ} \mathrm{C}$ \\
\hline \multicolumn{2}{|c|}{ Sulfito Reducing Anaerobes } & $1 \mathrm{ml}$ deep (tube) & $\begin{array}{l}\text { Tryptone-Sulfite-Néomycyne } \\
\text { (TSN) }\end{array}$ & $18-24 \mathrm{H}$ at $37^{\circ} \mathrm{C}$ \\
\hline \multicolumn{2}{|c|}{ LacticFlora (NF ISO 15214-1998 [3]) } & $1 \mathrm{ml}$ in the mass (double layer) & MRS & $24-48 \mathrm{H}$ at $37^{\circ} \mathrm{C}$ \\
\hline \multirow{3}{*}{ Salmonella } & Pre-enrichment & $25 \mathrm{~g}$ d'échantillon $+225 \mathrm{~g}$ d' EPT & Buffered Peptone Water & $18 \mathrm{H} \pm 2$ at $37^{\circ} \mathrm{C}$ \\
\hline & Enrichment & $\begin{array}{l}0.1 \mathrm{ml} \text { of pre-enrichment in RV } \\
\text { broth and } 2 \mathrm{ml} \text { in BSC Bouillon }\end{array}$ & $\begin{array}{l}\text { Broth Rappaport (RV) and } \\
\text { Selenite Cystine Broth (BSC) }\end{array}$ & $\begin{array}{l}\text { RV } 24 \mathrm{H} \pm \text { at } 41^{\circ} \mathrm{C} ; \\
\text { BSC } 24 \mathrm{H} \pm 2 \text { at } 37^{\circ} \mathrm{C}\end{array}$ \\
\hline & Isolation & $\begin{array}{l}\text { Spread one öse of each broth on the } \\
\text { surface of one box of each agar } \\
\text { isolation medium }\end{array}$ & $\begin{array}{l}\text { Salmonella/Shigella (SS) agar } \\
\text { Hektoen agar }\end{array}$ & $\begin{array}{l}\text { The whole } 24 \mathrm{H} \pm 2 \\
\text { at } 37^{\circ} \mathrm{C}\end{array}$ \\
\hline
\end{tabular}

dardization, Metrology and Quality Control (ANM)) in the Standard (NB 03.06.007 [15]).

Mould colonies in powder form were isolated in pure culture by transplantation on Potato Dextrose Agar (PDA) for 2 to 6 days incubation at $30{ }^{\circ} \mathrm{C}$ and $25^{\circ} \mathrm{C}$. The microscopic characters were observed by taking a mycelial fragment using a sterile platinum loop; which was deposited on a slide bearing a drop of cotton blue lactophenol (Guiraud and Galzy, 1980; Nguymen, 2007 [27]). The colonies were observed with an optical microscope at $\times 100$ magnification with immersion oil.

\section{Results}

3.1. Level status of hygiene during agbelima production The assessment of the state of hygiene shows that the production sites are in an unacceptable state and that the personnel are not trained about Good Hygiene Practices (GHP) and Good Manufacturing Practices (GMP). Producers and workers have never carried out any medical examination in the context of agbelima production. The maintenance of work equipment and their obsolescence is a major problem. The raw material, the production equipment as well as the producers are in an unhealthy environment without proper waste and wastewater management. The water used for washing the peeled cassava roots, for starch extraction and for packaging the finished product is of questionable quality. The cassava peelings and other waste mixed with the washing water left at the processing site create an unhealthy environment; giving off a very strong smell of ammonia. Drainage systems are archaic and the juice from the pressing runs off and fulfilled the soil.

\subsection{Adjusting the pre-processing program}

The prerequisite program corresponds to the first 5 steps of the HACCP principle. Thus, a program of periodic medical check-ups has been proposed, at least once a year. Similarly, any injured, sick or indisposed person must be excluded from production operations. In addition, the procedures of Good Hygiene Practices/Manufacturing for the realization of the unit operations aiming at ensuring the hygienic quality of agbelima have been established. Most of the adjustments proposed for quality assurance are adopted by the actors and implemented.

\subsection{Proposed HACCP model for the agbelima pro- duction chain \\ 3.3.1. Building the team}

Considering the nature of agbelima production, which is purely artisanal, and the low level of literacy of the producers and workers, some difficulties were encountered in making the team multidisciplinary.

The team was able to bring together 5 members who are:

- a qualitician (graduate microbiologist and technologist);

- a cassava producer;

- a production manager;

- an agronomist;

- a quality assurance supervisor.

- Description of agbelima.

Agbelima, is a product derived from cassava roots obtained after peeling, crushing, pressing, fine grinding and fermentation. The most important stage of its production is fermentation. Generally agbelima is whitish, beige or yellowish in color.

- Use of the product.

Agbelima is used to prepare a fermented paste with an elastic consistency commonly called agbéli in the mina dialect, a food resulting from the culinary knowledge in South Benin precisely of the Guin and consumed by the population.

- Diagram of agbelima production.

The technologies listed are variable and cover several steps grouped and ordered. Although producers have their own method of performing each unit operation, some operations are common to all producers. After reception, the cassava roots are peeled. The peeled roots are washed and soaked in water and then crushed in the grinder to obtain a grind. The latter is subjected to the action of a handcrafted and manual press. Then, the fine grind is obtained using a mill before being packaged in bags lined internally with transparent polyethylene (PE) bags. Finally, the fermentation follows, which is spontaneous (Figure 1). 


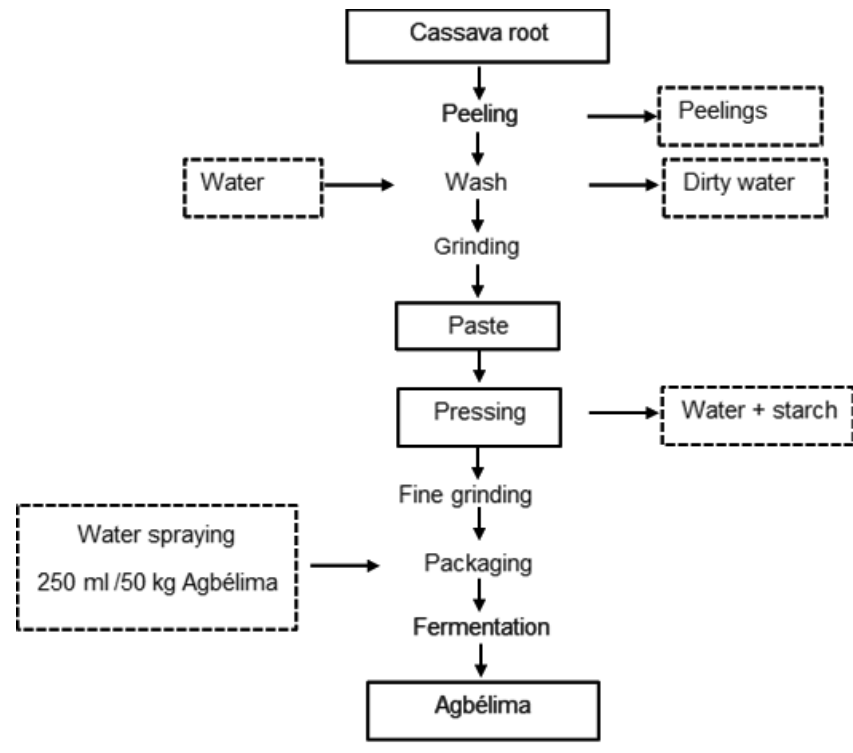

Fig. 1. Diagram of agbelima production from cassava roots

\subsubsection{Principle 1: Potential Hazards Identified}

The potential dangers that can reduce the quality of agbelima are the following:

- rotted cassava roots;

- damaged cassava roots;

- non-potable cassava root washing water;

- grains of sand stuck to the washed roots;

- thermophilic pathogenic microorganisms present in poorly washed mills;

- airborne pathogenic microorganisms and/or unclean pouches and bags;

- pathogenic microorganisms from unclean hands;

- Heavy metals released from the mill and grinder;

- product contact with flies and insects.

\subsubsection{Principle 2: Critical control points identified for} agbelima production

The Critical Control Points (CCPs) identified for agbelima production are grouped in Table 3.

CCP for agbelima production and these critical limits for each control measure

Table 3

\begin{tabular}{|c|c|c|c|c|}
\hline $\mathrm{CCP}$ & Unit operations & $\begin{array}{l}\text { Potential hazards or quality } \\
\text { defects }\end{array}$ & Control/preventive measures & Critical limits for control measures \\
\hline $\mathrm{CCP} 1$ & $\begin{array}{l}\text { Root reception } \\
\text { fresh from } \\
\text { cassava }\end{array}$ & $\begin{array}{l}\text { - Rotted cassava roots; } \\
\text { - Damaged cassava roots }\end{array}$ & $\begin{array}{l}\text { — Processing immediately after harvest- } \\
\text { ing; } \\
\text { — Removal of damaged cassava roots) }\end{array}$ & $\begin{array}{l}\text { - Process the cassava roots } \\
\text { within } 24 \text { hours of harvesting; } \\
\text { - Sorting on receipt }\end{array}$ \\
\hline $\mathrm{CCP} 2$ & $\begin{array}{l}\text { Washing } \\
\text { cassava roots }\end{array}$ & $\begin{array}{l}\text { - Pathogenic microor- } \\
\text { ganisms in the water used } \\
\text { to wash cassava roots; } \\
\text { - Sand grains stuck } \\
\text { to washed roots }\end{array}$ & $\begin{array}{l}\text { - Use drinking water from public water } \\
\text { supply or cooled boiled water; } \\
\text { - Treat all other water before use; } \\
\text { - Wash the cassava roots at least twice; } \\
\text { - Make sure that glued mud and sands } \\
\text { are completely removed from all parts and } \\
\text { contours of the roots }\end{array}$ & $\begin{array}{l}\text { - Total absence of dust, flies, } \\
\text { faeces, or offensive odours } \\
\text { in the area of the water source; } \\
\text { - Total absence of sand or } \\
\text { mud on the washed roots }\end{array}$ \\
\hline $\mathrm{CCP} 3$ & Grinding & $\begin{array}{l}\text { - Pathogenic thermophilic } \\
\text { microorganisms from dirty or } \\
\text { poorly cleaned mills; } \\
\text { - Metals from rusty and } \\
\text { poorly maintained shredders; } \\
\text { - Toxic elements released } \\
\text { by nets }\end{array}$ & $\begin{array}{l}\text { - Pathogenic thermophilic microorgan- } \\
\text { isms from dirty or poorly cleaned mills; } \\
\text { - Metals from rusty and poorly main- } \\
\text { tained shredders; } \\
\text { - Toxic elements released by nets }\end{array}$ & $\begin{array}{l}\text { - Total absence of impurities } \\
\text { inside and outside the mills; } \\
\text { — No use of mosquito net }\end{array}$ \\
\hline $\mathrm{CCP} 4$ & Pressing & $\begin{array}{l}\text { Pathogenic microorganisms } \\
\text { in a dirty and unhygienic } \\
\text { pressing environment or dirty } \\
\text { pressing bags }\end{array}$ & $\begin{array}{l}\text { - Use clean (disinfected) polypropylene } \\
\text { bags; } \\
\text { - Cleaning the presses; } \\
\text { - Avoid contact of the pressing bags with } \\
\text { dirty/soil surfaces; } \\
\text { - Clean and dry all bags at the end of } \\
\text { each working day; } \\
\text { - Treat all bags weekly with hot water } \\
\text { and/or disinfectant }\end{array}$ & $\begin{array}{l}\text { Total absence of dirt on bags } \\
\text { and pressing equipment }\end{array}$ \\
\hline CCP5 & Fine grinding & $\begin{array}{l}\text { - Pathogenic thermophilic } \\
\text { microorganisms from unclean } \\
\text { or poorly cleaned mills; } \\
\text { - Metals from rusty and } \\
\text { poorly maintained mills }\end{array}$ & $\begin{array}{l}\text { - Use clean mills; } \\
\text { - Clean mills regularly; } \\
\text { - Make sure that the mills are cleaned } \\
\text { before and after the end of the day's } \\
\text { operation; } \\
\text { - Make sure there are no lumps } \\
\text { in the cassava roots }\end{array}$ & $\begin{array}{l}\text { - Total absence of impurities } \\
\text { inside and outside the mills; } \\
\text { — Fine grinding }\end{array}$ \\
\hline CCP6 & Packaging & $\begin{array}{l}\text { - Pathogenic microorgan- } \\
\text { isms from dirty hands; } \\
\text { - Contact of product with } \\
\text { flies; } \\
\text { - Dirty bags and packaging } \\
\text { bags }\end{array}$ & $\begin{array}{l}\text { - Wash hands thoroughly with soap and } \\
\text { water; } \\
\text { - Make sure that the packaging bags are } \\
\text { not perforated; } \\
\text { - Make sure that the bags and packaging } \\
\text { bags are clean }\end{array}$ & $\begin{array}{l}\text { - No contact with the product } \\
\text { without proper hand washing; } \\
\text { - No observable openings } \\
\text { after closing the bags; } \\
\text { - No contact with flies; } \\
\text { - Hermetic sealing of bags }\end{array}$ \\
\hline
\end{tabular}


Establishment of the monitoring system

Table 4

\begin{tabular}{|c|c|c|c|c|c|c|c|}
\hline \multirow{2}{*}{$\mathrm{CCP}$} & \multirow{2}{*}{$\begin{array}{c}\text { Unit } \\
\text { operations }\end{array}$} & \multirow{2}{*}{$\begin{array}{l}\text { Potential hazards or } \\
\text { quality defect }\end{array}$} & \multicolumn{5}{|c|}{ Follow-up } \\
\hline & & & What & How & Frequency & Who & Registers \\
\hline $\mathrm{CCP} 1$ & $\begin{array}{l}\text { Root } \\
\text { reception } \\
\text { fresh from } \\
\text { cassava }\end{array}$ & $\begin{array}{l}\text { - Rotted cassava } \\
\text { roots; } \\
\text { - Damaged cassava } \\
\text { roots }\end{array}$ & $\begin{array}{l}\text { - Cultivar name; } \\
\text { - Maturity (months) } \\
\text { before harvest; } \\
\text { - Date and time of } \\
\text { harvest; } \\
\text { - Colour change, } \\
\text { evidence of damage; } \\
\text { - Presence of vascular } \\
\text { traces; } \\
\text { - Presence of brown } \\
\text { streaks }\end{array}$ & $\begin{array}{l}\text { - Investi- } \\
\text { gate at the } \\
\text { seller's level; } \\
\text { - Visual } \\
\text { inspecte }\end{array}$ & $\begin{array}{l}\text { For every } \\
\text { supply }\end{array}$ & $\begin{array}{l}\text { Quality } \\
\text { Assurance } \\
\text { Manager }\end{array}$ & $\begin{array}{l}\text { - Cultivar name; } \\
\text { - Age at harvest; } \\
\text { - Date and time of } \\
\text { harvest; } \\
\text { - Degree of colouring }\end{array}$ \\
\hline $\mathrm{CCP} 2$ & $\begin{array}{l}\text { Washing } \\
\text { cassava } \\
\text { roots }\end{array}$ & $\begin{array}{l}\text { - Pathogenic micro- } \\
\text { organisms in the water } \\
\text { used to wash cassava } \\
\text { roots; } \\
\text { - Sand grains stuck } \\
\text { to washed roots }\end{array}$ & $\begin{array}{l}\text { - Impurities } \\
\text { in the water; } \\
\text { - Fine particles; } \\
\text { - Sand grains and } \\
\text { odour; } \\
\text { - Particles of } \\
\text { sand or mud }\end{array}$ & \begin{tabular}{|l} 
Visual \\
inspecte
\end{tabular} & $\begin{array}{l}\text { - Water } \\
\text { Daily; } \\
\text { - Each } \\
\text { batch of } \\
\text { peeled } \\
\text { roots }\end{array}$ & \begin{tabular}{|l|} 
Pro- \\
duction \\
Super- \\
visor
\end{tabular} & $\begin{array}{l}\text { - Levels of dirt, fine } \\
\text { particles and materials } \\
\text { faecal; } \\
\text { - Presence or absence } \\
\text { of sand particles and } \\
\text { mud on the washed roots }\end{array}$ \\
\hline CCP3 & Grinding & $\begin{array}{l}\text { - Pathogenic thermo- } \\
\text { philic microorganisms } \\
\text { from dirty or poorly } \\
\text { cleaned mills; } \\
\text { - Metals from rusty } \\
\text { and poorly maintained } \\
\text { shredders; } \\
\text { - Toxic elements } \\
\text { released by nets }\end{array}$ & $\begin{array}{l}\text { Evidence of } \\
\text { rust or dirt } \\
\text { on grinders }\end{array}$ & $\begin{array}{l}\text { Visual } \\
\text { inspecte }\end{array}$ & $\begin{array}{l}\text { Before } \\
\text { and after } \\
\text { grinding }\end{array}$ & $\begin{array}{l}\text { Produc- } \\
\text { tion } \\
\text { Super- } \\
\text { visor }\end{array}$ & $\begin{array}{l}\text { - Absence of dirt or } \\
\text { rotten cassava paste from } \\
\text { the crushing operation } \\
\text { carried out } 24 \text { hours } \\
\text { previously; } \\
\text { - Degree of rust and } \\
\text { cleanliness of the grind- } \\
\text { ers }\end{array}$ \\
\hline CCP4 & Pressing & $\begin{array}{l}\text { Pathogenic microor- } \\
\text { ganisms in a dirty and } \\
\text { unhygienic pressing } \\
\text { environment or dirty } \\
\text { pressing bags }\end{array}$ & $\begin{array}{l}\text { Dirt on pressing equip- } \\
\text { ment and bags }\end{array}$ & $\begin{array}{l}\text { Visual } \\
\text { inspecte }\end{array}$ & $\begin{array}{l}\text { Before, } \\
\text { during } \\
\text { and after } \\
\text { pressing }\end{array}$ & $\begin{array}{l}\text { Control } \\
\text { Super- } \\
\text { visor }\end{array}$ & Absence of dirt \\
\hline CCP5 & $\begin{array}{l}\text { Fine grind- } \\
\text { ing }\end{array}$ & $\begin{array}{l}\text { - Pathogenic thermo- } \\
\text { philic microorganisms } \\
\text { from unclean or poorly } \\
\text { cleaned mills; } \\
\text { - Metals from rusty } \\
\text { and poorly maintained } \\
\text { mills }\end{array}$ & $\begin{array}{l}\text { Evidence of rust or dirt } \\
\text { on mills }\end{array}$ & $\begin{array}{l}\text { Visual } \\
\text { inspecte }\end{array}$ & $\begin{array}{l}\text { Before } \\
\text { and after } \\
\text { grinding }\end{array}$ & \begin{tabular}{|l|} 
Produc- \\
tion \\
Super- \\
visor
\end{tabular} & $\begin{array}{l}\text { Degree of rust and clean- } \\
\text { liness of mills }\end{array}$ \\
\hline CCP6 & Packaging & $\begin{array}{l}\text { - Pathogenic micro- } \\
\text { organisms from dirty } \\
\text { hands; } \\
\text { - Contact of product } \\
\text { with flies } \\
\text { - Dirty bags and } \\
\text { packaging bags }\end{array}$ & $\begin{array}{l}\text { - Suitability of hand } \\
\text { washing by staff; } \\
\text { - Cleanliness of } \\
\text { the bags; } \\
\text { - Correct closing of } \\
\text { the bags }\end{array}$ & $\begin{array}{l}\text { Visual } \\
\text { inspecte }\end{array}$ & \begin{tabular}{|l|} 
Before \\
and \\
after each \\
packaging
\end{tabular} & $\begin{array}{l}\text { Produc- } \\
\text { tion } \\
\text { Super- } \\
\text { visor }\end{array}$ & $\begin{array}{l}\text { - Level of cleanliness } \\
\text { of hands and bags; } \\
\text { - Condition of dam- } \\
\text { aged or undamaged bags }\end{array}$ \\
\hline
\end{tabular}

\subsubsection{Principle 3: Critical limits for each control mea-} sure for CCPS

For agbelima, the critical limits that must be achieved by control measures as an indication of adequate controls at each CCP are detailed in Table 3.

\subsubsection{Principle 4: Established monitoring system}

The monitoring system developed makes it possible to know what needs to be monitored, how monitoring should be done, how often monitoring should be done, and who does the monitoring. For agbelima production, the monitoring system put in place is shown in Table 4.

3.3.6. Principle 5: Specification of corrective actions to be taken when processes are out of control
Corrective actions on the diagram correspond to suggestions and/or proposals made and presented in Table 5.

\subsubsection{Principle 6: Procedure for verification of system} effectiveness

The procedure for verifying the effectiveness of the system put in place led to the results of the analysis of agbelima's marketable and hygienic quality (Table 6).

3.3.8. Principle 7: Documentation of all system implementation activities

All procedures followed for the implementation of the HACCP system and the results of observations and tests must be documented. All records must be maintained in an accessible manner. 
Corrective actions for critical control points that deviate from agbelima production

\begin{tabular}{|c|c|c|c|}
\hline $\mathrm{CCP}$ & Operation of the unit & Significant risks or quality defects & Corrective actions \\
\hline $\mathrm{CCP} 1$ & $\begin{array}{l}\text { Root reception } \\
\text { fresh from cassava }\end{array}$ & $\begin{array}{l}\text { - Rotted cassava roots; } \\
\text { - Damaged cassava roots }\end{array}$ & $\begin{array}{l}\text { - Reject undesirable cultivar, discoloured or old roots; } \\
\text { - Redirect untreated roots supplied more than } 72 \text { hours } \\
\text { after harvest into other fermented cassava products or } \\
\text { into pods for animal feed }\end{array}$ \\
\hline $\mathrm{CCP} 2$ & $\begin{array}{l}\text { Washing cassava } \\
\text { roots }\end{array}$ & $\begin{array}{l}\text { - Pathogenic microorganisms in the water } \\
\text { used to wash cassava roots; } \\
\text { - Sand grains stuck to washed roots }\end{array}$ & $\begin{array}{l}\text { Hanging the washing water or water source } \\
\text { Notify the staff responsible for washing the roots to be } \\
\text { re-washed }\end{array}$ \\
\hline $\mathrm{CCP} 3$ & Grinding & $\begin{array}{l}\text { - Pathogenic thermophilic } \\
\text { microorganisms from dirty or poorly } \\
\text { cleaned mills; } \\
\text { - Metals from rusty and poorly } \\
\text { maintained shredders; } \\
\text { - Toxic elements released by nets } \\
\end{array}$ & Clean the grinders before and after use. \\
\hline $\mathrm{CCP} 4$ & Pressing & $\begin{array}{l}\text { - Pathogenic microorganisms in a dirty } \\
\text { and unhygienic pressing environment or } \\
\text { dirty pressing bags }\end{array}$ & $\begin{array}{l}\text { - Repeat or continue the pressing operation by } \\
\text { increasing the pressure of the pressing machines during } \\
\text { the pressing operation; } \\
\text { - Cleaning the bags, rewashing the presses }\end{array}$ \\
\hline CCP5 & Fine grinding & $\begin{array}{l}\text { - Pathogenic thermophilic } \\
\text { microorganisms from unclean or poorly } \\
\text { cleaned mills } \\
\text { - Metals from rusty and poorly } \\
\text { maintained mills }\end{array}$ & $\begin{array}{l}\text { - Clearn the mills before and after grinding; } \\
\text { - Remove dirt and rust }\end{array}$ \\
\hline CCP6 & Packaging & $\begin{array}{l}\text { - Pathogenic microorganisms from dirty } \\
\text { hands; } \\
\text { - Contact of product with flies; } \\
\text { - Dirty bags and packaging bags }\end{array}$ & $\begin{array}{l}\text { - Instruct staff to wash their hands thoroughly with } \\
\text { soap and water; } \\
\text { - Avoid air entrance }\end{array}$ \\
\hline
\end{tabular}

Verification procedures

\begin{tabular}{|c|c|c|c|}
\hline $\mathrm{CCP}$ & Operation of the unit & Significant risks or quality defects & Vérification \\
\hline $\mathrm{CCP} 1$ & $\begin{array}{l}\text { Root reception } \\
\text { fresh from cassava }\end{array}$ & $\begin{array}{l}\text { - Rotted cassava roots; } \\
\text { - Damaged cassava roots }\end{array}$ & Humidity level \\
\hline $\mathrm{CCP} 2$ & Washing cassava roots & $\begin{array}{l}\text { - Pathogenic microorganisms in the water used } \\
\text { to wash cassava roots } \\
\text { - Sand grains stuck to washed roots }\end{array}$ & $\begin{array}{l}\text { Conducting a microbiological evaluation of } \\
\text { water samples and final products }\end{array}$ \\
\hline CCP3 & Grinding & $\begin{array}{l}\text { - Pathogenic thermophilic microorganisms } \\
\text { from dirty or poorly cleaned mills; } \\
\text { - Metals from rusty and poorly maintained } \\
\text { shredders; } \\
\text { — Toxic elements released by nets }\end{array}$ & $\begin{array}{l}\text { Microbiological analysis of the paste obtained, } \\
\text { the surface and the interior of the mills }\end{array}$ \\
\hline $\mathrm{CCP} 4$ & Pressing & $\begin{array}{l}\text { Pathogenic microorganisms in a dirty and } \\
\text { unhygienic pressing environment or dirty } \\
\text { pressing bags }\end{array}$ & $\begin{array}{l}\text { - Repeat or continue the pressing operation } \\
\text { by increasing the pressure of the pressing } \\
\text { machines during the pressing operation; } \\
\text { - Cleaning the bags, rewashing the presses }\end{array}$ \\
\hline CCP5 & Fine grinding & $\begin{array}{l}\text { - Pathogenic thermophilic microorganisms } \\
\text { from unclean or poorly cleaned mills; } \\
\text { - Metals from rusty and poorly maintained } \\
\text { mills }\end{array}$ & $\begin{array}{l}\text { - Clearn the mills before and after grinding; } \\
\text { - Remove dirt and rust }\end{array}$ \\
\hline CCP6 & Packaging & $\begin{array}{l}\text { - Pathogenic microorganisms from dirty hands; } \\
\text { - Contact of product with flies; } \\
\text { - Dirty bags and packaging bags }\end{array}$ & $\begin{array}{l}\text { - Instruct staff to wash their hands } \\
\text { thoroughly with soap and water; } \\
\text { - Avoid air ingress }\end{array}$ \\
\hline
\end{tabular}

3.4. Principle 6: Effectiveness of the HACCP system on the microbiological quality of agbelima samples

Before the application of the HACCP method, small lumps of cassava root were observed in agbelima. More the packaging of the final product suffered from big defects of presentation. At the end of the implementation of the HACCP system, a better control of the milling was observed which allowed agbelima to have a fine and uniform texture. In addition, Agbelima is packed in new variable capacity bags $(100 \mathrm{~kg}, 50 \mathrm{~kg}$ and 30 $\mathrm{kg}$ ). Its bags are lined inside with new polyethylene bags. The clean packaging materials and the bags that are impermeable guarantee the healthy nature of Agbelima and the preservation of its nutrients, physical appearance and sensory qualities. These packaging materials do not give agbelima any undesirable smell. This improves the marketable quality of agbelima after HACCP. 
Comparison of microbiological parameters before and after HACCP*

\begin{tabular}{|c|c|c|c|c|c|c|c|c|c|c|c|c|}
\hline \multirow{2}{*}{$\begin{array}{l}\text { Parameters } \\
\text { Samples }\end{array}$} & \multicolumn{2}{|c|}{ Total Mesophilic Flora $\times 10^{6}$} & \multicolumn{3}{|c|}{ Lactic Flora $\times 10^{6}$} & \multicolumn{4}{|c|}{ Yeasts $\times 10^{4}$} & \multicolumn{3}{|c|}{ Molds $\times 10^{4}$} \\
\hline & $\begin{array}{c}\text { Before } \\
\text { HACCP }\end{array}$ & $\begin{array}{c}\text { After } \\
\text { HACCP }\end{array}$ & Before HACCP & \multicolumn{2}{|c|}{$\begin{array}{c}\text { After } \\
\text { HACCP }\end{array}$} & \multicolumn{2}{|r|}{$\begin{array}{l}\text { Before } \\
\text { HACCP }\end{array}$} & \multicolumn{2}{|c|}{$\begin{array}{l}\text { After } \\
\text { HACCP }\end{array}$} & \multicolumn{2}{|c|}{ Before HACCP } & $\begin{array}{c}\text { After } \\
\text { HACCP }\end{array}$ \\
\hline $\mathrm{AT}_{1} \mathrm{~A}_{\mathrm{g}}$ & $40,83 \pm 1,44$ & $3,93 \pm 0,31$ & $18,20 \pm 9,01$ & \multicolumn{2}{|c|}{$3,05 \pm 0,24$} & \multicolumn{2}{|c|}{$2050,0 \pm 1925,5$} & \multicolumn{2}{|c|}{$21,17 \pm 20,28$} & \multicolumn{2}{|c|}{$193,3 \pm 188,8$} & $2,05 \pm 1,93$ \\
\hline $\mathrm{AT}_{1} \mathrm{H}$ & $88,40 \pm 75,13$ & $4,27 \pm 2,06$ & $65,33 \pm 8,08$ & \multicolumn{2}{|c|}{$1,667 \pm 0,91$} & \multicolumn{2}{|c|}{$3103,3 \pm 2650,3$} & \multicolumn{2}{|c|}{$33,33 \pm 23,23$} & \multicolumn{2}{|c|}{$523,3 \pm 225,0$} & $1,42 \pm 0,63$ \\
\hline $\mathrm{AT}_{2} \mathrm{~A}_{\mathrm{g}}$ & $108,0 \pm 98,55$ & $7,27 \pm 8,46$ & $13,57 \pm 9,62$ & \multicolumn{2}{|c|}{$3,067 \pm 2,57$} & \multicolumn{2}{|c|}{$843,3 \pm 310,9$} & \multicolumn{2}{|c|}{$51,00 \pm 25,36$} & \multicolumn{2}{|c|}{$600,0 \pm 427,2$} & $3,67 \pm 2,31$ \\
\hline $\mathrm{AT}_{2} \mathrm{H}$ & $106,33 \pm 89,79$ & $8,90 \pm 4,91$ & $39,33 \pm 1,42$ & \multicolumn{2}{|c|}{$1,100 \pm 0,49$} & \multicolumn{2}{|c|}{$123,3 \pm 102,1$} & \multicolumn{2}{|c|}{$23,33 \pm 5,03$} & \multicolumn{2}{|c|}{$56,7 \pm 45,1$} & $3,00 \pm 2,65$ \\
\hline $\mathrm{AT}_{3} \mathrm{~A}_{\mathrm{g}}$ & $336,67 \pm 148,44$ & $5,10 \pm 3,31$ & $93,3 \pm 5,13$ & \multicolumn{2}{|c|}{$2,667 \pm 2,08$} & \multicolumn{2}{|c|}{$1123,3 \pm 1377,9$} & \multicolumn{2}{|c|}{$5,97 \pm 4,42$} & \multicolumn{2}{|c|}{$98,3 \pm 93,9$} & $2,67 \pm 1,15$ \\
\hline $\mathrm{AT}_{3} \mathrm{H}$ & $83,0 \pm 15,72$ & $12,00 \pm 3$ & $40,67 \pm 5,13$ & 6,067 & 0,90 & & $3,3 \pm 2573,6$ & $78,33 \pm$ & ,56 & 516 & $7 \pm 453,7$ & $6,00 \pm 1,73$ \\
\hline Parameters & Staphyloco & $\mathrm{ci} \times 10^{2}$ & $\begin{array}{r}\text { Colifo } \\
\text { Thermotc }\end{array}$ & & & 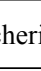 & hia coli & $\begin{array}{r}\text { Sulfito- } \\
\text { Ana }\end{array}$ & & & Salı & onella \\
\hline & $\begin{array}{l}\text { Before } \\
\text { HACCP }\end{array}$ & $\begin{array}{l}\text { After } \\
\text { HACCP }\end{array}$ & $\begin{array}{l}\text { Before } \\
\text { HACCP }\end{array}$ & $\begin{array}{l}\text { After } \\
\text { HACCP }\end{array}$ & $\begin{array}{l}\text { Bef } \\
\text { HAC }\end{array}$ & & $\begin{array}{l}\text { After } \\
\text { HACCP }\end{array}$ & $\begin{array}{l}\text { Before } \\
\text { HACCP }\end{array}$ & & & $\begin{array}{l}\text { Before } \\
\text { HACCP }\end{array}$ & $\begin{array}{l}\text { After } \\
\text { HACCP }\end{array}$ \\
\hline AT1Ag & $90,0 \pm 55,7$ & $0,02 \pm 0,03$ & $57 \pm 35$ & $3 \pm 3$ & $15 \pm$ & & $<1$ & $8 \pm 2$ & & & Abs & Abs \\
\hline AT1H & $786,7 \pm 320,2$ & $0,36 \pm 0,31$ & $37 \pm 15$ & $2 \pm 2$ & $6 \pm$ & & $<1$ & $4 \pm 3$ & $<$ & & Prés & Abs \\
\hline AT2Ag & $1210 \pm 800,2$ & $0,05 \pm 0,05$ & $158 \pm 167$ & $<1$ & $17 \pm$ & & $<1$ & $58 \pm 52$ & $<$ & & Prés & Abs \\
\hline AT2H & $466,7 \pm 208,2$ & $0,02 \pm 0,02 \pm$ & $119 \pm 110$ & $<1$ & $63 \pm$ & & $<1$ & $4 \pm 2$ & $<$ & & Prés & Abs \\
\hline AT3Ag & $290 \pm 173,5$ & $0,10 \pm 0,09$ & $16 \pm 15$ & $3 \pm 2$ & $4 \pm$ & & $<1$ & $47 \pm 38$ & $<$ & & Prés & Abs \\
\hline AT3H & $7366,7 \pm 5744,9$ & $0,02 \pm 0,03$ & $14 \pm 15$ & $3 \pm 2$ & $1 \pm$ & & $<1$ & $13 \pm 6$ & $<$ & & Abs & Abs \\
\hline
\end{tabular}

*Notes: Not all values of the averages follow standard microbiological rules for recording results; this is to keep the power bases common and compare the decimal base for each parameter; $\mathrm{A}=$ agbelima; $\mathrm{T}=$ technology; $\mathrm{Ag}=$ agrick; $\mathrm{H}=$ hombete; $\times=$ factor

The hygienic quality control of the various productions of agbelima before and after the implementation of the system has enabled to assess the health impact of HACCP on agbelima (Table 7). The results obtained show a significant reduction in the number of floral loads counted.

The average loads in Total Mesophilic Flora are between 4.08 $\pm 0.14 .10^{7}$ and $3.37 \pm 1.48 .10^{8} \mathrm{CFU} / \mathrm{g}$ before and between $3.93 \pm 0.31 .106$ and $1.2 \pm 0.3 .10^{7} \mathrm{CFU} / \mathrm{g}$ after HACCP, a reduction of $96.43 \%$ of maximum load. The average Lactic Flora corresponds to a maximum value of $9.33 \pm 5.13 .10^{7} \mathrm{CFU} / \mathrm{g}$ and a minimum of $1.36 \pm 0.96 .10^{7} \mathrm{CFU} / \mathrm{g}$ before the application of the system. These values range from $1.1 \pm 0.49 .10^{6} \mathrm{CFU} / \mathrm{g}$ to $6.07 \pm 0.9 .10^{6} \mathrm{CFU} / \mathrm{g}$ after HACCP, a reduction of $93.49 \%$ in maximum load. The maximum yeast value is $3.1 \pm 2.65 .10^{7}$ CFU/g before HACCP and 7.8 $\pm 1.75 .10^{5} \mathrm{CFU} / \mathrm{g}$ after HACCP, a reduction of $97.47 \%$ in maximum load. For Molds, the average values are between $5.67 \pm 4.51 .10^{5}$ and $6 \pm 4.27 .10^{6} \mathrm{CFU} / \mathrm{g}$ before and $1.42 \pm 0.63 .10^{4}$ and $6 \pm 1.73 .10^{4} \mathrm{CFU} / \mathrm{g}$ after HACCP, a reduction of $99 \%$ of maximum load. Staphylococci presumed to be pathogenic are present in all samples and their average value varies from $9 \pm 5.57 .10^{3} \mathrm{CFU} / \mathrm{g}$ to $7.37 \pm 5.74 .10^{5}$ before HACCP, then from $2 \pm 2 \mathrm{CFU} / \mathrm{g}$ to $36 \pm 31$ after HACCP, a reduction of $99.99 \%$ of the maximum load. Nevertheless, $100 \%$ compliance with the normative value (less than $10^{2}$ $\mathrm{CFU} / \mathrm{g}$ ) was observed after HACCP for Staphylococci. The maximum average thermotolerant coliforms went from $1.5 \pm 1.67 .10^{2}$ before HACCP to $3 \pm 3 \mathrm{CFU} / \mathrm{g}$ after HACCP, a reduction of $98.10 \%$ reduction in maximum load. All samples analyzed after HACCP met the normative criterion (less than $10 \mathrm{CFU} / \mathrm{g}$ ) for this parameter. The maximum averages of E. coli and Sulfito-Reducing Anaerobes are respectively
$63 \pm 35 \mathrm{CFU} / \mathrm{g}$ and $58 \pm 52 \mathrm{CFU} / \mathrm{g}$ before HACCP. A total absence of these parameters was recorded after HACCP, a reduction of $100 \%$ maximum load reduction and $100 \%$ compliance. Salmonella is absent from the samples after the HAC$\mathrm{CP}$ concept has been implemented.

\subsection{Conformity of the system with the HACCP im-} plementation guide

The 12 steps of the HACCP approach are the top of the radar (Figure 2). Analysis of this figure shows that only steps E3, E4, E5, E6 and E7 are 100\% compliant, followed by steps E9, E1, E8, E10 and E2, which are 90\%, 85\%, 75\%, $70 \%$ and $70 \%$ compliant respectively. On the other hand, low compliance with HACCP requirements is observed at steps 11 and 12 (E11 and E12), indicating significant deviations in the implementation of the HACCP approach at the production site. It is the verification and transcription steps (HACCP manual, procedure guide, recordings) that appear to be cumbersome for the breeders.

\section{Discussion}

The different hazards are identified at each level of production and control measures are provided when the HACCP system is applied. The effectiveness of this system has been evaluated through the analysis of the microbiological quality (marketable, organoleptic and hygienic) of agbelima samples.

\subsection{Conditions of personal hygiene and of the agbe- lima production site}

Hygiene on the production site and in the immediate environment is very decisive for the quality of the finished prod- 


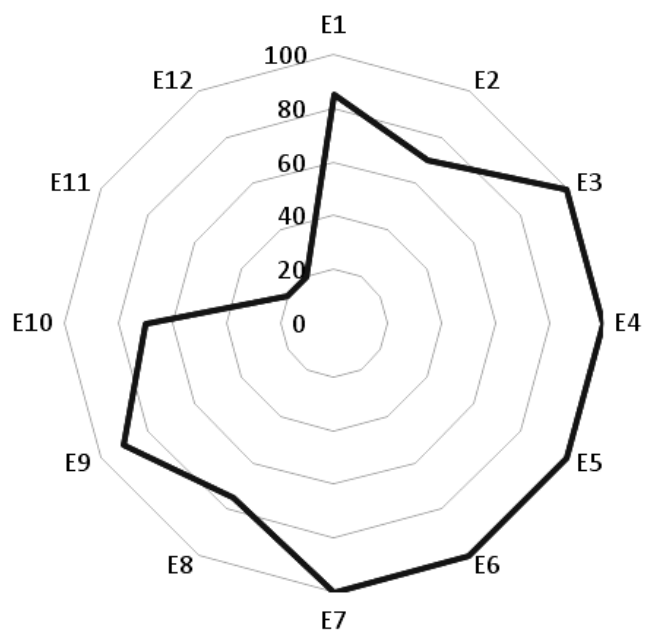

Fig. 2. Compliance of the system with the HACCP implementation guide

uct. It must be ensured at the beginning, during and at the end of each production process. It has been noted that there are inadequacies and irregularities in terms of hygiene, which do not make either the sellers or the consumers of agbelima feel safe. The management of garbadge and waste dirty water is a real environmental problem. The absence of channels for the evacuation of waste water leads to the formation of stagnant water points. Thus, larval gites are created and consequently lead to permanent and/or temporary insalubrity. The work of Assanvo et al (2002) [19], on the production sites of attièkè confirms that observations made. The result is a remarkable presence of flies, which are real carriers of biological contaminants such as Salmonella sp., E. coli, etc. (Robyn et al., 1995 [39]). Furthermore, Smith (1986) [40] in his work reported that food produced in an unhealthy environment is susceptible to contamination by flies and domestic animals.

The poor hygienic condition of equipment related to agbelima production can contribute to a proliferation of epiphytic and even pathogenic germs. In the same way, these conditions are sources of alteration. Indeed, several researchers have reported the role played by production equipment as well as its conservation environment in contamination by Listeria monocytogenes (Miettinen et al., 1999 [34]; Aguado et al., 2001 [16]; Suihko et al., 2002 [41]; Aarnisalo et al., 2006 [1]). Consumption of a product contaminated by flies and pets causes ailments such as diarrhoea, vomiting etc. to consumers (Smith, 1986 [40]). Non-compliance with Good Hygienic/Manufacturing Practices is identified as a major factor of contamination in this study.

The observations made on food safety before the application of the HACCP concept reveal the potential sources of contamination of agbelima. This does not guarantee product quality assurance. However, by analysing this chain of transformation of cassava roots into agbelima, the HACCP team that was set up proposed concrete safety measures at each critical point for the control of the entire transformation chain.

\subsection{Market and hygienic quality of agbelima samples before HACCP}

The small lumps of cassava root observed in agbelima, and the often recycled packaging materials, lead to a defect in the presentation of the product. This alters the marketable quality of agbelima before HACCP.

Agbelima being a fermented product, the high value of the Total Flora cannot be interpreted as a lack of hygiene since it is confused with that of the Total Fermented Flora.

The maximum value of the Lactic Flora corresponding to $9.33 \pm 5.13 .107 \mathrm{CFU} / \mathrm{g}$ in the samples of Agbelima contributes to the improvement of the organoleptic qualities, acidification, stabilisation and conservation of the product. It also improves the digestibility, energy value, nutritional, sanitary and prophylactic quality of the food (Raimbiault, 1995 [38]). These bacteria are the residual wild flora of cassava roots. This flora is responsible for the fermentation process that leads to the production of derived products (Yandju, 1994 [47]; Moorthy and Mathew, 1998 [35]).

Since the total flora counted is the same as the total fermentative flora, the evaluation of the hygiene of the products is based on the presence of $E$. coli and Staphylococci. In fact, all the agbelima samples analysed do not comply with the guide value $\left(10^{2} \mathrm{CFU} / \mathrm{g}\right)$ for Staphylococci. The high rate of non-conformity $(100 \%)$ of Staphylococci, coupled with their large number $\left(1.4 .10^{6} \mathrm{UFC} / \mathrm{g}\right)$ is due to a purely artisanal and manual production, since this germ is a natural flora of man (skin, hair, nostrils, mouth) and testifies to an insufficient personal hygiene of the handlers (Lobe, 2009 [32]). The identification of the Staphylococci enumerated reveals the species Staphylococcus aureus, reputed to be dangerous because of its thermoresistant toxins. Compared to the presence of $E$. coli, an indicator of faecal contamination, the high rate of non-compliance $(100 \%)$ recorded is due to the production environment, in particular wind, dust and also contamination of human origin linked to the uncleanliness of hands and the use of soiled equipment.

As far as fungal flora is concerned, the yeasts counted also belong to the fermentative flora of agbelima. As for Moulds, the lowest load detected $\left(5.67 .10^{5} \mathrm{UFC} / \mathrm{g}\right.$ of product analysed) is well above the normative value of $5 \mathrm{UFC} / \mathrm{g}$ of product analysed. They come essentially from the natural flora of the cassava roots used by the producers. Other studies have also reported their presence in food products of plant origin (Wells, 1972 [46]; Garrido et al., 1992 [42]). The species identified are Aspergillus flavus, Aspergillus fumigatus which are heat-resistant mycotoxin-producing strains (Tidjani et al., 2007 [43]).

\subsection{Effectiveness of the HACCP system}

Agbelima, obtained after the application of the HACCP system, has a fine and uniform appearance. This product is packed in new materials. The fineness of Agbelima, the clean and new condition of the packaging materials improve the market value of Agbelima after HACCP.

The microbiological quality control of the various productions of agbelima before and after the application of HAC$\mathrm{CP}$ has made it possible to evaluate its sanitary impact on agbelima. The reduction of the loads in flowers after the implementation of the HACCP system shows the efficiency of the system 98,30\%. Considering the thermotolerant Coliforms, for the 18 samples analysed at each stage, the conformity of $0 \%$ before HACCP passes to $100 \%$ after HACCP of that of Staphylococci varying from $0 \%$ to $100 \%$ before and after HACCP a good hygiene of the workers. The compliance of 
$50 \%$ observed for Salmonella before HACCP and rising to $100 \%$ in all samples after HACCP means that hygiene measures have been complied with.

By obscuring the inhibitory effect of lactic flora on pathogenic strains in fermented products (Yateem et al., 2008 [48]; Hanchi et al., 2009 [28]; Dib et al., 2012 [26]; Capo-chichi et al, 2013 [25]), the decrease in thermotolerant coliforms and staphylococci and the absence of $E$. coli can be explained by the application of Good Hygienic/Manufacturing Practices required throughout the production chain (Agassounon Djikpo Tchibozo et al., 2009 [10]; Agassounon Djikpo Tchibozo et al., 2016 [12]).

The absence of Salmonella sp. in all samples is an indication that the handlers of the product do not suffer from salmonella infection and that the hygiene measures were followed. These results are in accordance with the standard used (NB 03.06.007 [15]) which requires the absence of Salmonella in $25 \mathrm{~g}$.

The compliance with the implementation guide is $77.5 \%$ compared to the 12 steps after the application of the system. Improvements are still needed, especially on the registrations and their actual updating.

\section{Conclusion}

This study devoted to the implementation of a quality approach on the production chain of agbelima, allowed to establish the importance of quality tools in all companies, even craft ones. The HACCP approach applied to the production of agbelima has contributed to the reduction of the germs of alteration of the product. This study also has the merit of having provided information that can be used to establish a guide of Good Hygiene and Manufacturing Practices that can be used by agbelima producers to guarantee the safety of products for human consumption. However, the observation of precautions in the determination of critical points, critical limits or the scrupulous application of procedures is not sufficient to eliminate all the health risks to which consumers are exposed, it is still necessary to regularly test the effectiveness of the system.

\section{References}

1. Aarnisalo K., Tallavaara K., Wirtanen G., Maijala R., Raas$\mathrm{ka} \mathrm{L}$. The hygienic working practices of maintenance personnel and equipment hygiene in the Finnish food industry. Food Control, 2006. 17 (12): 1001-1011.

2. Abraham N. Characterisation of a subgenomic molecule associated with South African cassava mosaic virus. Availlable on http:// hdl.handle.net/10539/12365. Consulté le 17/12/1018. 2013.

3. AFNOR (NF ISO 15214-1998): microbiologie des aliments méthode horizontale pour le dénombrement des bactéries lactiques mésophile.

4. AFNOR (NF ISO 4832-2006): microbiologie alimentaire directives générales pour le dénombrement des coliformes-méthodes par comptage des colonies.

5. AFNOR (NF ISO 6888-1-1999): microbiologie alimentaire méthode horizontale pour le dénombrement des staphylocoques à coagulase positive partie 1 .

6. AFNOR (NF ISO 7218): Microbiologie Alimentaire règle générales pour les examens microbiologiques.

7. AFNOR (NF ISO 7954-1998/V08-022): microbiologie alimentaire directives générales pour le dénombrement des levures et moisissures-technique par comptage des colonies à $25^{\circ} \mathrm{C}$.
8. AFNOR (NF V 04-501: 1998). Microbiologie des aliments et les aliments pour animaux. Préparation des échantillons. Pour l'analyse microbiologique de la viande et les produits point de vue de la suspension initiale et la dilution.

9. AFNOR (NF V 08-051:1999). Analyses microbiologiques des produits agro - alimentaires (59) - Accréditation $\mathrm{n}^{\circ} 1-0632$ (convention $\mathrm{n}^{\circ}$ 311).

10. Agassounon Djikpo Tchibozo M., Ahissou H., Ahanhanzo C. et Toukourou F. Appréciation des qualités microbiologiques et nutritionnelles de la boisson «bissap» issue de la technologie traditionnelle améliorée. J. Rech. Sci. Univ. Lomé. 2009. 11 (1): 11-19.

11. Agassounon Djikpo Tchibozo M., Tadjou A., Anago D. G., Dovonou E. F., Ayi-Fanou L. Qualité physico-chimique et bactériologique des eaux de boisson dans les arrondissements de la commune de Kétou au Bénin. Revue de Microbiologie Industrielle, Sanitaire, et Environnementale (REMISE), 2014. 8 (2), 187-207.

12. Agassounon Djikpo Tchibozo M., Anago D. G., Guidi T. C., Chégnimonhan V., Galimova L. V., Savadogo A., Alladagniwèkè M., Ameyapoh B. Application of HACCP System and Quality of Yoghurt Production in a Small and Medium Enterprise (SME) of Dairy Products in Benin Republic. Journal of International Academy of Refrigeration. 2016. No. 4. P. 3-10.

13. Agence Nationale de Normalisation, de Métrologie et du Contrôle Qualité (ANM) (NB $0111007-2006$ ) Microbiologie Directives pour la préparation des dilutions en vue de l'examen microbiologique.

14. Agence Nationale de Normalisation, de Métrologie et du Contrôle Qualité (ANM) (NB 0111 008-2006) Microbiologie Alimentaire Directives Générales pour le dénombrement des aéorobies mésophiles.

15. Agence Nationale de Normalisation, de Métrologie et du Contrôle Qualité (ANM) (NB 03.06.007). Lafun — Spécifications. Ed. 2007. 7 p.

16. Aguado V., Vitas A. I., Garcia-Jalon I. Random ampliWed polymorphic DNA typing applied to the study of cross-contamination by Listeria monocytogenes in processed food products. Journal of Food Protection. 2001. 64 (5): 716-720.

17. Akouègninou A., van der Burg W. J., van der Maesen L. J. G. Flore analytique du Bénin. Cotonou \& Wageningen Edition Backhuys Publishers. 2006. 1034 p.

18. Amoa-Awua W. K. A., Appoh F. E., Jakobsen M. Lactic acid fermentation of cassava dough into agbelima. International Journal of Food Microbiology, 1996. 31: 87-98.

19. Assanvo J. B., Agbo G. N., Behi Y. E. N., Coulin P., Farah. Z. La microflore du ferment de manioc pour le preparation de l'attiéké Adjoukrou à Dabou (Côte d'Ivoire). Bioterre, Revue Internationnale Sciences de la Vie et de la Terre, $\mathrm{N}^{\circ}$ special. Acte du colloque international, Centre Suisse, du 27-29 Août 2001. 2002.

20. Benesi I. R. M., Labuschagne M. T., Dixon A. G. O., Mahungu N. M. Genotype X environment interaction effects on native cassava starch quality and potential for starch in the commercial sector. African Crop Science Journal. 2005. 12: 205-216.

21. Bentancor A., Rumi M. V., Gentilini M. V., Sardoy C., Irinio K., Agostini A., Cataldi A. Shiga toxin- producing and attaching and effacing Escherichia coli in cats and dogs in a high hemolytic uremic syndrome incidence region in Argentina. FEMS Microbiol Letter. 2007. 267: 251-256.

22. Bokanga M. Cassava, post-harvest opérations, éd. International Institute of Tropical Agriculture (IITA), Ibadan, Nigeria, 2001. $220 \mathrm{p}$. 
23. Bourgeois C. M. et Leveau J. Y. Technique d'analyse et contrôle dans les industries agroalimentaires. Contrôle microbiologique. 1991. Vol. 3, pp. 327-334.

24. Capo-Chichi R. Caractérisation des germes épiphytes responsables de la fermentation d'agbélima. Mémoire de Master de Microbiologie et de Technologies Alimentaires, FAST/UAC, 2010. 62 p.

25. Capo-Chichi R., Agassounon M. T. D, Adoukonou-Sagbadja H., Anago D. G., Ayi-Fanou L., Karou S. D., Ahanhanzo C., De Souza C. Evolution du pH et des microflores fermentaires de Agbelima produit à pahou au Benin. Journal de la Recherche Scientifique de l'Universite de Lomé. 2013. 15 (2): $1-11$

26. Dib H., Hajj Semaan E., Mrad R., Ayoub J., Choueiry L., Moussa H., Bitar G., Identification et évaluation de l'effet probiotique des bactéries lactiques isolées dans des fromages caprins traditionnels lebanese. Science Journal. 2012. 13 (1): 43-58.

27. Guiraud J., Galzy P. L'analyse microbiologique dans les industries agroalimentaire, Collection génie alimentaire. Les éditions de l'usine nouvelle, Paris, France, 1980. 239 p.

28. Hanchi H., Kourda S. R., Ben H., Amida J. Etude comparative de la microflore industrielle et artisanale des laits caillé «raieb» et fermenté «leben» tunisiens. Microbiol. Hyg. Alim., 2009. 21 (62): 73-78.

29. Hongbètè F., Mestres C., Akissoé N., Pons B., Hounhouigan D., Cornet D., Nago C. M. Effects of cultivar and harvesting conditions (age, season) on the texture and taste of boiled cassava roots. Food Chemistry, 2011. 126 (1), 127-133.

30. Konfo C. T., Chabi N. W., Agbadjizo J., Dahouenon-Ahoussi E., Soumanou M. M., Sohounhloue D. C. Influence de la feuille de Hemizygia bracteosa (Benth) sur la qualité de la bière du sorgho» tchakpalo» produite au Bénin. International Journal of Innovation and Applied Studies, 2014.7 (2): 453-463.

31. Le Barbé G., Alé G., Millet B., Texier H., Boret Y., Gualde R. Les ressources en eaux superficielles de la République du Bénin. 1993. $540 \mathrm{p}$.

32. Lobe H. Vérification de l'efficacité du système HACCP dans le cadre de la production des filets de poissons frais dans une usine au Sénégal: Cas d'Amerger Casamance. Mémoire de Master 2 de Qualité des Aliments de l'Homme, Université Cheikh Anta Diop de Dakar. 2009. 144 p.

33. Mananga Luzembo F., 2012. Analyse de la qualité par le système HACCP des cossettes de manioc produites à Kisantu au sein de la fondation LZB. Université pédagogique nationale-graduat en sciences agronomiques

34. Miettinen M. K., Björkroth K. J., Korkeala H. J. Characterization of Listeria monocytogenes from an ice cream plant by sero-typing and pulsed-Weld gel electrophoresis. International Journal of Food Microbiology, 1999. 46 (3):187-192.
35. Moorthy S. N., Mathew G. Cassava fermentation and associated changes in physicochemical and functional. Critical Reviews in food Science and Nutrition. 1998. 38: 73-212.

36. Nago C. M., Hounhouigan D. J. La transformation alimentaire traditionnelle des racines et tubercules au Bénin. Les publications du CFRNA / N², Cotonou, Bénin, 1998. 97 p.

37. Nguymen M. M. Identification des espèces de moisissures potentiellement productrices de mycotoxines dans le riz commercialise dans cinq provinces de la région centrale du VITNAM: étude de condition pouvant réduire la production de mycotoxine: thèse de doctorat. INSpolytechnique de Toulouse. 2007. 147 p.

38. Raimbiault M. Importance des bactéries lactiques dans les fermentations du manioc. T. Agbor Egbe, A. Brauman, D. Griffon, S. Trèche (ed) 1995, éditions ORSTOM. 1995.

39. Robyn E. O., John A. G., Kenneth J. D., Rob R. Coliforms in processed mango: Significance and control. Food Microbiology. 1995. 25: 51-61.

40. Smith A. Pets and vectors in an urban environment. Working Paper. Joint FAO/WHO expert consultation on food protection for urban consumers. FAO, Rome 1986.

41. Suihko M. L., Salo S., Niclasen O., Gudbjörnsdótti B., Torkelsson G., Bredholt S. Characterization of Listeria monocytogenesisolates from the meat, poultry and seafood industries by automated ribotyping. International Journal of Food Microbiology. 2002. 72 (1-2): 137-146.

42. Garrido D., Jordal M., Pozzo R. Mould flora and aflatoxin-producing strains of Aspergillus flavus. Indian J. Mycol. Plant Pathol., 1992. 21: 211-212.

43. Tidjani A., Agassounon Djikpo Tchibozo M., Ameyapoh Y., Toukourou Fatiou de Souza C. Essais de conservation des viandes séchées «Kilichi» commercialisées au Tchad: Etude de la stabilité microbiologique. J. Recher. Sci. Univ., 2007. P. 9-17.

44. Toka M. D., Djenit N., Djem K. Improved process of cassava processing into "Attiéké', a traditional food product of Côte D’Ivoire. Int. J. Food Eng. 2008. 4: 24-29.

45. Turyagyenda L. F., Kizito E. B., Ferguson M. E., Baguma Y., Harvey J. W., Gibson P., Wanjala B. W., Osiru D. S. O. Genetic diversity among farmer-preferred cassava landraces in Uganda. African Crop Science Journal, 2012. 20 (1): 15-30.

46. Wells T. R., Kreutzer W. A. Aerial invasion of peanut floor tissue by Aspergillus flavus under genotobiotic conditions. Phytopathology. 1972. Vol. 62, p. 797.

47. Yandju D. Rôle des microorganismes dans la fermentation des racines de manioc (Manihot esculenta Crantz). Thèse de doctorat. Université de Kisangani.1994.

48. Yateem A., Balba M. T., AL-Surrayai T., Al-Mutairi, B. and Al-Daher, R. Isolation of lactic acid bacteria with probiotic potential from camel milk. International Journal of Dairy Science. 2008. 3 (4): 194-199. 


\section{Information about authors}

\section{Agassounon Djikpo Tchibozo Micheline}

D. Sc., Professor, Head of Laboratory of Norms and Microbiology, Nutritional and Phytogalenic Control, University of Abomey

(UAC), Benin, BP. Cotonou 526/01, tchibowo@yahoo.fr

\section{Capo-Chichi Romaine}

Doctoral student of Department of Genetic and Biotechnology, University of Abomey (UAC), Benin, BP. Cotonou 526/01, capo_rome@yahoo.fr

\section{Adjagodo Antoinette}

D., Department of Genetic and Biotechnology,

University of Abomey (UAC), Benin, BP. Cotonou 526/01, adjadogo.antoinette@yahoo.fr

\section{Ladekan Eléonore}

D., Associate professor, Master-Conference, University of Abomey (UAC), Benin, BP. Cotonou 526/01, eleoyayi@yahoo.fr

\section{Guidi Tognon Clotilde}

D. Sc., Professor, Deputy Director of the National Higher Institute of Technology of Lokossa, National Higher Institute of Technology of Lokossa/ National University of Sciences, Technologies, Engineering and Mathematics of Benin, BP133 Lokossa, guidi65@mail.ru

\section{Galimova Larissa V.}

D. Sc., Professor, Professor of the Department Heat and power engineering and refrigerating machines, Astrakhan State Technical University, Russia, 414056, Astrakhan, Tatishcheva str., 16, galimova_lv@mail.ru

\section{Сведения об авторах}

\section{Агассунон Жикпо Щибозо Мишлине}

Д. б. н., профессор, Зав. лабораторией норм и микробиологии, пищевого и фитогаленового контроля, Университет Абомеу Калави, Бенин, tchibowo@yahoo.fr

\section{Капо-Шиши Ромаине}

Аспирант кафедры Генетики и биотехнологий, Университет Абомеу Калави, Бенин, capo_rome@yahoo.fr

\section{Аджагодо Антуанетте}

К. б. н., кафедра генетики и биотехнологий, Университет Абомеу Калави, Бенин, adjadogo.antoinette@yahoo.fr

\section{Ладекан Елеоноре \\ К. б. н., доцент, Мастер-конференция, Университет Абомеу Калави, Бенин, eleoyayi@yahoo.fr}

\section{Гуиди Тогнон Клотильде}

Д. т. н., профессор, Заместитель директора Локосского государственного технологического института, Национальный университет наук, технологий, инженерии и математики Бенина, ВР 133 Локосса, guidi65@mail.ru

\section{Галимова Лариса Васильевна}

Д. т. н., профессор, профессор каф. Теплоэнергетика и холодильные машины, Астраханский государственный технический университет, Россия, 414056, г. Астрахань, ул. Татищева, 16, galimova_lv@mail.ru

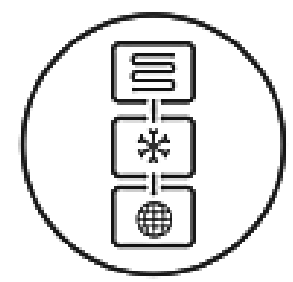

\section{$7^{\text {th }}$ IIR Conference on Sustainability and the Cold Chain}

The IIR conference series on Sustainability and the Cold Chain is recognised as a cutting-edge event on the cold chain which addresses the ever-increasing demand for knowledge-sharing in this essential sector.

This prestigious biennial conference attracts international audiences of researchers and industrialists, providing an opportunity to showcase the latest developments in sustainability, retail refrigeration and the cold chain.

\section{Start date: April 01, 2022}

End date: April 30, 2022

Location: Newcastle, United Kingdom Main commissions: Refrigerating equipment; Cryobiology, cryomedicine; Food science \& engineering

- Themes: Cold chain, interfaces

- $\quad$ Keywords: Cold chain; Sustainability

Organisers:

IOR (Institute of Refrigeration, UK)

Contact: iccc2020@sciencesconf.org

Official websites:

https://iifiir.org/en/events/7th-iir-conference-on-sustainability-and-the-cold-chain 